\title{
Correlation between perfusion density and ganglion cell layer thickness in non-diabetic subjects and diabetic patients without retinopathy
}

\section{Correlación entre la densidad de perfusión y el grosor de la capa de células ganglionares, en sujetos sin diabetes y en pacientes diabéticos sin retinopatía}

\author{
Guillermo Serrato-Martín ${ }^{1}$, Dulce M. Razo-Blanco-Hernández ${ }^{2 *}$, Selma A. Somilleda-Ventura ${ }^{3}$, and \\ Virgilio Lima-Gómez ${ }^{1}$ \\ ${ }^{1}$ Ophthalmology Service, Hospital Juárez de México; ${ }^{2}$ Research Division, Hospital Juárez de México; ${ }^{3}$ Center for Biomedical Research, Fundación \\ Hospital Nuestra Señora de la Luz I.A.P. Mexico City, Mexico
}

\begin{abstract}
Purpose: To compare the correlation between perfusion density and ganglion cell layer thickness in non-diabetic subjects and diabetics without retinopathy. Methods: Non-experimental, retrospective, comparative cross-sectional study in subjects without diabetes (group 1) and diabetics without retinopathy (group 2) evaluated with optical coherence tomography and optical coherence tomography angiography (Cirrus with Angioplex). We compared perfusion density between groups by quadrants ( $3 \times 3 \mathrm{~mm}$ map), ganglion cell layer thickness by sectors (Mann Whitney's $U$ ) and the correlation between variables within groups (Spearman's Rho). Results: Thirty-four subjects in group 1, 38 in group 2. Inner, total, superior and nasal perfusion densities were lower in group $2(p<0.05)$; ganglion cell layer thickness did not differ between groups in any sector. There were weak correlations between inner and total perfusion densities and ganglion cell layer thicknesses in group 1; in group 2 there were weak correlations between inferior quadrant perfusion and ganglion cell layer thickness in the inferior and inferior temporal sectors, where perfusion density did not differ from group 1. Conclusions: The correlation between perfusion density and ganglion cell layer thickness is weak in non-diabetic subjects; diabetics without retinopathy show no correlation, observing only a lower perfusion density.
\end{abstract}

Key words: Ganglion cells. Correlation. Perfusion density. Diabetes. Ganglion cell layer thickness. Retina.

\section{Resumen}

Objetivo: Comparar la correlación entre la densidad de perfusión y el grosor de la capa de células ganglionares en sujetos sin diabetes y diabéticos sin retinopatía. Método: Estudio observacional, retrospectivo, comparativo y transversal, en sujetos sin diabetes (grupo 1) y diabéticos sin retinopatía (grupo 2) evaluados mediante tomografía de coherencia óptica y angiotomografía de coherencia óptica (Cirrus con Angioplex). Se compararon entre grupos la densidad de perfusión por cuadrantes (mapa de $3 \times 3 \mathrm{~mm}$ ), el grosor de la capa de células ganglionares por sectores (U de Mann-Whitney) y la correlación

\section{Correspondence:}

Dulce M. Razo-Blanco-Hernández

Avda. Instituto Politécnico Nacional, 5160

Col. Magdalena de las Salinas, G.A. Madero Date of reception: 18-09-2020

C.P. 07760, Mexico City, Mexico

E-mail: razoblanco.dulce@gmail.com
Available online: $21-05-2021$

Rev Mex Oftalmol (Eng). 2021;95(3):92-97

www.rmo.com.mx

2604-1731/C 2020 Sociedad Mexicana de Oftalmología. Published by Permanyer. This is an open access article under the CC BY-NC-ND license (http://creativecommons.org/licenses/by-nc-nd/4.0/). 
entre variables por grupo (Rho de Spearman). Resultados: Se incluyeron 34 sujetos en el grupo 1 y 38 en el grupo 2. Las densidades de perfusión interna, completa, superior y nasal fueron menores en el grupo $2(p<0.05)$; el grosor de la capa de células ganglionares no difirió entre grupos en ningún sector. Hubo correlaciones débiles entre la densidad de perfusión interna y completa y los grosores de la capa de células ganglionares en el grupo 1; en el grupo 2 hubo correlaciones débiles entre la perfusión del cuadrante inferior y el grosor de los sectores inferior e inferior temporal, donde la densidad de perfusión no difirió de la del grupo 1. Conclusiones: La correlación entre la densidad de perfusión y el grosor de la capa de células ganglionares es débil en los sujetos sin diabetes y se pierde en los pacientes diabéticos sin retinopatía, porque en ellos solo la densidad de perfusión es menor.

Palabras clave: Células ganglionares. Correlación. Densidad de perfusión. Diabetes. Grosor de la capa de células ganglionares. Retina.

\section{Introduction}

Diabetic retinopathy is one of the main preventable causes of blindness in subjects of working age $\mathrm{e}^{1,2}$. Traditionally it has been considered as a microvascular disease, specific to diabetes; however, before its clinical manifestations appear, spectral domain-optical coherence tomography can detect changes in the ganglion cell layer thickness ${ }^{3}$. Another characteristic prior to the development of diabetic retinopathy is the decrease in parafoveal capillary density, identified by optical coherence tomography angiography ${ }^{4,5}$; both characteristics can coexist. Kim, et al. ${ }^{6}$ have reported a strong correlation between the progression of changes in the ganglion cell layer thickness and vascular density $(r=$ 0.616-0.871), as well as between ganglion cell layer thickness and perfusion density $(r=0.371-0.555)^{6}$.

The reduction in capillary density could decrease the ganglion cell layer thickness, but the proportion in which contributes to these changes before the onset of diabetic retinopathy has not been determined. Among the OCT-angiographic variables with the Cirrus Angioplex, vascular density measures the length of the detected capillaries, while perfusion density measures the percentage of macular area with capillary flow?. The correlation between perfusion density and ganglion cell layer thickness in different regions of the macula could estimate the contribution of the former to the changes in the latter.

The objective of this study was to compare the correlation between perfusion density and ganglion cell layer thickness in non-diabetic subjects and diabetics without retinopathy.

\section{Methods}

An observational, retrospective, comparative and cross-sectional study was carried out in subjects without diabetes and diabetic patients without diabetic retinopathy from Mexico City and its metropolitan area. The sample was obtained from patients treated in a federal referral hospital between January 27 and January 31,2020 , during a campaign to detect macular diseases using optical coherence tomography. The study adhered to the principles of the Declaration of Helsinki and received authorization from the research and research ethics commissions at the institution where it was carried out (registry HJM 0782/20-R).

We included subjects with age between 20 and 80 years, of both sexes, without diabetes or diabetics without diabetic retinopathy, who had a spectral optical coherence tomography test (macular thickness cube) and an optical coherence tomography angiography test ( $3 \times 3 \mathrm{~mm}$ perfusion map) of adequate quality, with a signal intensity $>7$. Cases whose tests had an inadequate image quality or measurement errors, and those in which fundus photography or optical coherence tomography revealed data of retinopathy or other ocular diseases, were eliminated.

All participants were evaluated under a standardized protocol by a single investigator, as described below: corrected visual acuity measured in Snellen equivalent, $45^{\circ}$ fundus photographs under pharmacological mydriasis (Visucam lite, Zeiss, Dublin, CA, USA) and measurement of center point thickness, macular volume, ganglion cell layer thickness, perfusion density and the characteristics of the foveal avascular zone, in a $3 \times 3 \mathrm{~mm}$ map, with the HD-OCT Cirrus 5000 with Angioplex (Zeiss, Dublin, CA, USA), using the OMAG algorithm.

Subjects without diabetes were assigned to group 1 and patients with diabetes were assigned to group 2 . One eye per patient was selected using random numbers program.

The evaluated variables were ganglion cell layer thickness, which was defined by the automatic measurement of the thickness of the neurosensory retina delimited by the inner plexiform layer and the nerve fiber layer, and macular perfusion density, defined as 
Table 1. Comparison of baseline variables between groups (median and interquartile range)

\begin{tabular}{|c|c|c|c|}
\hline Variable & Group $1(n=34)$ & Group $2(n=38)$ & $\mathbf{p}$ \\
\hline Age (years) & $46(33.7-60.5)$ & $56(49.7-60.5)$ & $0.005^{*}$ \\
\hline Center point thickness $(\mu \mathrm{m})$ & $250(237.5-268)$ & $250.5(232-265.5)$ & $0.513^{*}$ \\
\hline Macular volume $\left(\mathrm{mm}^{3}\right)$ & $10.1(9.9-10.5)$ & $9.9(9.7-10.3)$ & $0.222^{*}$ \\
\hline Foveal avascular zone area $\left(\mathrm{mm}^{2}\right)$ & $0.28(0.21-0.36)$ & $0.30(0.19-0.38)$ & $0.939^{*}$ \\
\hline Foveal avascular zone perimeter (mm) & $2.28(2.02-2.76)$ & $2.52(2.06-2.82)$ & $0.720^{*}$ \\
\hline Circularity of the foveal avascular zone (\%) & $0.68(0.59-0.73)$ & $0.63(0.49-0.70)$ & $0.172^{*}$ \\
\hline Female & $18(52.9 \%)$ & $24(63.2 \%)$ & $0.380^{\dagger}$ \\
\hline Arterial hypertension & 0 & $10(26.3 \%)$ & $0.001^{\dagger}$ \\
\hline
\end{tabular}

Table 2. Comparison of perfusion density between groups (Mann-Whitney U)

\begin{tabular}{|l|c|c|c|}
\hline Perfusion density $(\%)$ & Group $2(\mathrm{n}=38)$ & p \\
\hline Central & Group $1(\mathrm{n}=34)$ & $14.8(11.8-19.9)$ & 0.050 \\
\hline Inner & $18.7(13.9-22.5)$ & $37.8(35.9-39.3)$ & 0.012 \\
\hline Complete & $40.5(37.0-41.6)$ & $35.4(33.1-37.0)$ & 0.018 \\
Superior & $37.7(34.4-39.2)$ & $37.7(33.7-39.5)$ & 0.023 \\
\hline Temporal & $41.0(36.4-41.8)$ & $39.2(36.7-41.3)$ & 0.55 \\
Inferior & $40.3(37.2-41.4)$ & $38.4(35.3-39.6)$ & 0.09 \\
\hline Nasal & $39.1(37.2-41.8)$ & $37.6(35.1-39.7)$ & 0.01
\end{tabular}

the percentage of the macular surface where circulation was identified. Perfusion density was measured by quadrants: superior, temporal, inferior, and nasal. The ganglion cell layer thickness was measured by sectors: superior, superotemporal, inferotemporal, inferior, inferonasal and superonasal. We used the measurements of both variables that the equipment generated automatically.

A Kolmogorov-Smirnov test was performed, which revealed a non-normal distribution for some variables, for which the results were expressed as medians and interquartile ranges. The medians of the ganglion cell layer thickness and perfusion density were compared between groups using the Mann-Whitney $U$ test. The correlation between ganglion cell layer thickness in each sector and the perfusion density in each quadrant between groups, was determined using the Spearman's Rho test. A p-value of less than 0.05 was considered significant. The results were stored and analyzed in the
IBM SPSS program Ver. 26 (SPSS Inc, Chicago, IL, USA).

\section{Results}

Seventy-two eyes of 72 subjects were included, with an age of 20 to 77 years (median: 54.5; interquartile range: $43-60)$, and 42 were female $(58.3 \%)$. The time of evolution of diabetes ranged from 1 month to 18 years (median: 5 ; interquartile range: 2-12). Ten participants had arterial hypertension (13.9\%). Thirty-four subjects were assigned to group 1 and 38 to group 2 . The comparison between baseline variables is shown in Table 1; the median age and the frequency of arterial hypertension were higher in group 2.

Table 2 shows the comparison of perfusion density between groups; the median was lower in group 2, except for the temporal and inferior quadrants, in which there were no differences between groups. Central 
Table 3. Comparison of ganglion cell layer thickness between groups (Mann-Whitney U)

\begin{tabular}{|l|c|c|c|}
\hline Ganglion cell layer thickness $(\mathrm{\mu m})$ & Group $1(\mathrm{n}=34)$ & Group $2(\mathrm{n}=38)$ & 0.91 \\
\hline Superior & $83.0(77.7-86.2)$ & $82.5(77.0-88)$ & 0.29 \\
\hline Superotemporal & $81.5(77.0-86.0)$ & $80.0(77.2-84.0)$ & 0.59 \\
\hline Inferotemporal & $81.0(76.7-86.0)$ & $81.0(74.0-85.0)$ & 0.93 \\
\hline Inferior & $79.0(73.7-83.0)$ & $79.0(75.0-82.0)$ & 0.74 \\
\hline Inferonasal & $81.0(75.7-86.0)$ & $79.5(75.7-86.2)$ & 0.67 \\
\hline Superonasal & $83.5(78.8-88.5)$ & $83.0(77.7-88.2)$ & \\
\hline
\end{tabular}

Table 4. Correlation between perfusion density per quadrant and ganglion cell layer thickness per sector in group 1 ( $n=34$, Spearman's Rho)

\begin{tabular}{|l|c|c|c|c|c|}
\hline \multirow{2}{*}{ Perfusion density } & \multicolumn{5}{|c|}{ Ganglion cell layer thickness } \\
\cline { 2 - 6 } & Superior & Superotemporal & Inferotemporal & Inferior & Inferonasal \\
\hline Inner & $0.388(0.023)^{*}$ & $0.357(0.038)^{*}$ & $0.403(0.018)^{*}$ & $0.416(0.014)^{*}$ & $0.426(0.012)^{*}$ \\
\hline Complete & $0.381(0.026)^{*}$ & $0.403(0.018)^{*}$ & $0.425(0.012)^{*}$ & $0.385(0.024)^{*}$ & $0.369(0.032)^{*}$ \\
\hline Inferior & NS & NS & $0.358(0.037)^{*}$ & $0.365(0.034)^{*}$ & $0.368(0.032)^{*}$ \\
\hline Nasal & NS & NS & NS & NS & $0.394(0.021)^{*}$
\end{tabular}

\section{*p-value.}

NS: not significant.

Table 5. Correlation between perfusion density per quadrant and ganglion cell layer thickness per sector in group 2 ( $n=38$, Spearman's Rho)

\begin{tabular}{|l|c|c|c|c|c|}
\hline & \multicolumn{5}{|c|}{ Ganglion cell layer thickness } \\
\hline Perfusion density & Superior & Superotemporal & Inferotemporal & Inferior & Inferonasal \\
\hline Inner & NS & NS & $0.388(0.016)^{*}$ & $0.336(0.039)^{*}$ & NS \\
\hline Complete & NS & NS & $0.384(0.017)^{*}$ & $0.326(0.046)^{*}$ & NS \\
\hline Temporal & NS & NS & $0.403(0.012)^{*}$ & NS & NS
\end{tabular}

${ }^{*}$ p-value.

NS: not significant.

density showed a tendency to be lower in group 2 . Ganglion cell layer thickness did not differ between groups (Table 3).

The correlations between perfusion density and ganglion cell layer thickness in group 1 are presented in Table 4; there was a weak correlation between the internal and complete perfusion densities and the thicknesses of the sectors, with the exception of the superonasal. The thicknesses of the inferior sector showed a weak correlation with the perfusion density of the inferior quadrant.
In group 2, there was only a weak correlation between the inner and complete perfusion densities and the thickness of the inferior and inferotemporal sectors that corresponded with the quadrants where perfusion density did not differ between groups (Table 5).

\section{Discussion}

A lower perfusion density was observed in diabetic patients without retinopathy compared to healthy subjects; the difference was greater in the superior and 
nasal quadrants, which was sufficient to reduce both internal and complete perfusion densities. Ganglion cell layer thickness was similar in both groups; the correlations between perfusion density and ganglion cell layer thickness could not be compared, because most were not significant in group 2. The values of the ganglion cell layer thickness by sector in subjects without diabetes in our study were similar to those reported by Lee, et al. ${ }^{8}$ in a Korean study that used the same equipment for measurement; the values in diabetic patients without retinopathy were higher than those reported by them. This difference could be due to the fact that their study only included patients with more than 10 years of evolution of diabetes, which could reduce ganglion cell layer thickness; another explanation could be the variability between populations, as interracial differences in ganglion cell layer thickness have been reported ${ }^{9}$.

In subjects without diabetes, a weak correlation was observed between internal perfusion density and ganglion cell layer thickness in most sectors. This indicates that the variation of perfusion density does not explain all the changes in ganglion cell layer thickness. Most of these weak correlations were not observed in group 2, except for the sectors where perfusion density did not show differences between groups.

Kim, et al. ${ }^{6}$ reported a strong correlation between the decrease in ganglion cell layer thickness and four optical coherence tomography angiography parameters in diabetic patients without retinopathy or with non-proliferative diabetic retinopathy. Their longitudinal study showed progressive changes in a group that already had a reduction in both ganglion cell layer thickness and perfusion density, measured with the same equipment that we used in our study. In our study, only patients without diabetic retinopathy with a short time of evolution of diabetes were included, which would explain why no changes were observed in ganglion cell layer thickness, even when perfusion density had decreased. We did not find the correlations reported by the same group ${ }^{10}$ between ganglion cell layer thickness and the foveal avascular zone, because in our study the measurements of this region were similar between groups.

In this cross-sectional study, the lower perfusion density in patients with diabetes occurred without changes in ganglion cell layer thickness. For this stage of progression of the damage due to diabetes, perfusion density did not correlate with ganglion cell layer thickness because the latter did not change in the evaluated group. This does not indicate that a lower perfusion density does not alter ganglion cells. Instead, the reduction in perfusion density observed did not affect the thickness of this neural layer. The evaluated patients could correspond to a group in which vascular alterations precede neural damage, as suggested by Simó, et al. ${ }^{11}$ and Marques, et al. ${ }^{12}$ in their studies.

We did not observe a significant increase in the parameters of the foveal avascular zone in patients with diabetes, which has been a common finding in studies that report changes in the ganglion cell layer thickness $^{13,14}$. This could be because central perfusion density was not lower either. Rosen, et al..$^{15}$ have proposed that a very early change in diabetes is an increase in the density of perfused capillaries as a compensatory mechanism, particularly those closest to the foveal avascular zone. If this was the case in the eyes of our study, they would probably be in a stage prior to the decrease in ganglion cell layer thickness, but confirming this would require another type of design.

A variable that could have modified the results of the study is age, which was higher in patients with diabetes; however, the effect that could have occurred is a loss of ganglion cells, which would have reduced the thickness of this layer. A new study in subjects with more delimited age ranges and duration of diabetes would allow us to determine whether the findings of this study are consistent. Another limitation could be arterial hypertension, but in patients who suffer from it, the characteristic that is associated with a prolonged duration of the disease is a decrease in ganglion cell layer thickness ${ }^{16}$.

One strength of the study is the measurement of perfusion density by quadrants, which made it possible to identify the most affected regions of the parafovea and correlate their values with those of the ganglion cell layer thickness by sector. A potential limitation is the sample size, but the number of patients evaluated was sufficient to find statistical differences in perfusion density, even though ganglion cell layer thickness did not change.

The lower perfusion density was sufficient to show a statistical difference; however, the threshold required to observe a reduction in ganglion cell thickness is still unknown, and determining it will require a longitudinal evaluation of patients without diabetic retinopathy with a longer duration of diabetes, because the association between a reduction of both variables in patients with diabetic retinopathy ${ }^{17-20}$ has already been determined.

\section{Conclusions}

In patients with diabetes without retinopathy, no strong correlation was found between perfusion density 
and ganglion cell layer thickness, because the latter did not decrease compared to subjects without diabetes.

\section{Conflicts of interest}

The authors declare no conflicts of interest.

\section{Ethical disclosures}

Protection of human and animal subjects. The authors declare that no experiments were performed on humans or animals for this study.

Confidentiality of data. The authors declare that they have followed the protocols of their work center on the publication of patient data.

Right to privacy and informed consent. The authors declare that no patient data appear in this article.

\section{References}

1. Vujosevic S, Aldington SJ, Silva P, Hernández C, Scanlon P, Peto T, et al. Screening for diabetic retinopathy: new perspectives and challenges. Lancet Diabetes Endocrinol. 2020;8:337-47.

2. Moshfeghi AA, Lanitis T, Kropat G, Kuznik A, Gibson A, Feng $H$, et al. Social cost of blindness due to AMD and diabetic retinopathy in the United States in 2020. Ophthalmic Surg Lasers Imaging Retina. 2020;51:S6-S14.

3. Tang Z, Chan MY, Leung WY, Wong HY, Ng CM, Chan VTT, et al. Assessment of retinal neurodegeneration with spectral-domain optical coherence tomography: a systematic review and meta-analysis. Eye. 2020 Jun 24. doi: 10.1038/s41433-020-1020-z. Online ahead of print.

4. Furino C, Montrone G, Cicinelli MV, Balestra S, Grassi M, Reibaldi M, et al. Optical coherence tomography angiography in diabetic patients without diabetic retinopathy. Eur J Ophthalmol 2020;30:1418-23.

5. Gildea D. The diagnostic value of optical coherence tomography angiography in diabetic retinopathy: a systematic review. Int Ophthalmol. 2019;39:2413-33.
6. Kim K, Kim ES, Kim DG, Seung-Young Y. Progressive retinal neurodegeneration and microvascular change in diabetic retinopathy: longitudinal study using OCT angiography. Acta Diabetol. 2019;56:1275-82.

7. Rosenfeld PJ, Durbin MK, Rosiman L, Zheng F, Miller A, Robbins G ZEISS angioplex spectral domain optical coherence tomography angiography: technical aspects. Dev Ophthalmol. 2016;56:18-29.

8. Lee MW, Lee WH, Ryu CK, Kim TY, Lim HB, Lee YH, et al. Effects of prolonged type 2 diabetes on the inner retinal layer and macular microvasculature: an optical coherence tomography angiography study. J Clin Med. 2020;9:1849.

9. Chansangpetch S, Huang G, Coh P, Oldenburg C, Amoozgar B, He M, et al. Differences in optic nerve head, retinal fiber layer and ganglion cell complex parameters between Caucasian and Chinese subjects. J Glaucoma. 2018:27:350-6.

10. Kim K, Kim ES, Yu SY. Optical coherence tomography angiography analysis of foveal microvascular changes and inner retinal layer thinning in patients with diabetes. Br J Ophthalmol. 2018;102:1226-31.

11. Simó R, Stitt AW, Gardner TW. Neurodegeneration in diabetic retinopathy: does it really matter? Diabetologia. 2018;61:1902-12.

12. Marques IP, Alves D, Santos T, Mendes L, Santos AR, Lobo C, et al. Multimodal imaging of the initial stages of diabetic retinopathy: different disease pathways in different patients. Diabetes. 2019;68:648-53.

13. Li X, Xie J, Zhang L, Cui Y, Zhang G, Chen X, et al. Identifying microvascular and neural parameters related to the severity of diabetic retinopathy using optical coherence tomography angiography. Invest Ophthalmol Vis Sci. 2020;61:39.

14. Vujosevic S, Muraca A, Alkabes M, Villani E, Cavarzeran F, Rossetti L, et al. Early microvascular and neural changes in patients with type 1 and type 2 diabetes without clinical signs of diabetic retinopathy. Retina. 2019;39:435-45.

15. Rosen RB, Andrade Romo JS, Krawitz BD, Mo S, Fawzi AA, Linderman RE, et al. Earliest evidence of preclinical diabetic retinopathy revealed using optical coherence tomography angiography perfused capillary density. Am J Ophthalmol. 2019;203:103-15.

16. Santos AR, Ribeiro L, Bandello F, Lattansio R, Egan C, Frydkjaer OU, et al. Functional and structural findings of neurodegeneration in early stages of diabetic retinopathy: cross-sectional analyses of baseline data of the EUROCONDOR project. Diabetes. 2017;66:2503-10.

17. Lupidi M, Coscas G, Coscas F, Fiore T, Spaccini E, Fruttini D, et al. Retinal microvasculature in nonproliferative diabetic retinopathy: automated quantitative optical coherence tomography angiography assessment. Ophthalmic Res. 2017:58:131-41.

18. Park JJ, Chung CS, Fawzi A. Visualizing structure and vascular interactions: macular nonperfusion in three capillary plexuses. Ophthalmic Surg Lasers Imaging Retina. 2018;49:e-182-90.

19. Jung JJ, Yu DJG, Zeng A, Chen MH, Shi Y, Nassisi M, et al. Correlation of quantitative measurements with diabetic disease severity using multiple en face OCT angiography image averaging. Ophthalmol Retina. 2020;4:1069-82.

20. Lim HB, Lee MW, Park JH, Kim K, Jo YJ, Kim JY. Changes in ganglion cell-inner plexiform layer thickness and retinal microvasculature in hypertension: an optical coherence tomography angiography study. Am J Ophthalmol. 2019;199:167-76. 